\title{
Repetitive Extragenic Palindromic PCR (REP-PCR) as an Alternative Method for Detection of Bulking in Activated Sludge
}

\author{
DAGNA A. SOŁTYSIK, ILONA A. BEDNAREK*, TOMASZ M. LOCH, SABINA E. GAŁKA, \\ DANIEL J. SYPNIEWSKI, GRZEGORZ M. MACHNIK, DARIA K. BEASZCZYK
}

Department of Biotechnology and Genetic Engineering, Medical University of Silesia, Sosnowiec, Poland

Received 30 June 2009, revised 20 January 2010, accepted 25 January 2010

Abstract

\begin{abstract}
Bulking of activated sludge is a world-wide problem which negatively affects wastewater treatment efficiency. The most common reasons of bulking are bacterial community changes, especially excessive growth of filamentous bacteria (filamentous bulking) or excess of biopolymers on the surface of non-filamentous microbes (non-filamentous or Zoogleal bulking). Because of the complex nature of the bulking phenomenon finding a successful bulking control strategy remains a very important issue that awaits new options and advices. The REP-PCR fingerprinting method has been applied to distinguish a bacterial community in non-bulking and bulking activated sludge. The characteristic REP-PCR fingerprinting patterns were compared with each other in terms of the presence or absence of bands and in terms of measured integrated optical density (IOD) of the bands. The obtained fingerprinting patterns, using Ward's clustering method, have been analyzed to determine homology/similarity relations between specific non-bulking and bulking sludge sampling. The received clustering results were in high concordance with activated sludge typing which generally is done based on physicochemical sludge analysis. The proposed REP-PCR method and statistical analysis of fingerprinting patterns seems to be a simple, rapid and effective method revealing differences between populations in non-bulking and bulking activated sludge. It may be useful for routine activated sludge monitoring and may be helpful in the early detection of the bulking process.
\end{abstract}

K e y w ords: activated sludge bulking, REP-PCR fingerprinting, Ward's clustering

\section{Introduction}

Activated sludge process is one of the most popular methods of wastewater treatment. It is commonly used world-wide to neutralize industrial, municipal and domestic wastewater. In this method, wastewater treatment plants (WWTP's), beside mechanical steps of treatment, also utilize microorganisms for the purification of wastewaters. Microorganisms observed in activated sludge belong to different taxonomy group, the major group being the Eubacteria. Bacteria are responsible for removing organic substances which are present in wastewater. Complex organic compounds are decomposed into simple one as a result of complicated metabolic processes. However, beside Eubacteria, other microorganisms also occur in activated sludge: filamentous organisms - fungi, actinomycetes; protozoa: ciliate, flagellate, heliozoan and metazoan: rotifer, nematodes. All of these microorganisms create a specific community in which each group plays an important role in the entire activated sludge process. The quantitative participation of individual microorganism groups changes seasonally and depends on temperature, $\mathrm{pH}$ or waste composition (Mehandjiyska, 1995; Lacko et al., 1999).

Filamentous structure and capability of production of an extracellular polymeric substance (EPS) by most microorganisms is responsible for the creation of activated sludge flocks. The structure of these flocks determines the efficiency of wastewater treatment in the activated sludge process. Loose structures of flocks decreases settleability which is their most restrictive attribute. Poor settlement has a negative effect on the critical stage of the process - sedimentation and separation of microbial biomass from effluent stream. This observed unwanted effect is called bulking of activated sludge.

The most widely cited possible reasons of bulking process are: excessive growth of filamentous bacteria, (continuous competition between filaments and

* Corresponding author: I. Bednarek, Department of Biotechnology and Genetic Engineering, Medical University of Silesia, Narcyzów 1 Street, 41-200 Sosnowiec, Poland; phone: (+48) 32 3641040; e-mail: dribednarek@sum.edu.pl 
flock-formers), and overproduction of extracellular polymeric substances by non-filamentous microbes (mainly Zooglea). Excess production of biopolymers brings about agglomeration of microorganisms and interferes with the sedimentation process. Other reasons for worse settleability of flocks may be the presence of toxic substances in wastewater, as well as not enough or too many nutrients for microbes which causes loose structure of flocks and their dispersion in wastewater. The storage phenomenon, (the formation of storage compounds such as polyphosphates, glycogen, and polyhydroxyalkanoates inside flockforming cells) is one of the hypotheses for explaining the bulking problem (Hossain, 2004; Kalisz and Kaźmierczuk, 1998, Martins et al., 2003).

Bulking problem is world-widely prevalent, occurs independent of municipal or industrial WWTP's (Wang et al., 2006; Eikelboom and Geurkink, 2002). Therefore, for a very long time scientists have been trying to find possible control strategies for the bulking problem.

Recent development in genetics give a chance to find a solution to bulking problems by using molecular methods. Several molecular techniques have been proposed in the literature to analyze temporary changes in bacterial community structure. Molecular methods such as Fluorescent In Situ Hybridization (FISH) (Ziembińska et al., 2007; Liao et al., 2004; Carr et al., 2003), 16S rDNA clone libraries (Otawa et al., 2006), $16 \mathrm{~S}-$ restriction fragment length polymorphism, (16SRFLP), (Gilbride and Fulthorpe, 2004) or ribosomal intergenic spacer analyses (RISA), (Baker et al., 2003), have already been applied to the study of waste-waterassociated microbial communities. Most molecular techniques being used are based on the detection of $16 \mathrm{~S}$ rRNA pools and genomic fingerprinting pattern analysis of microbial population. To obtain genomic fingerprinting patterns different molecular techniques are used, e.g. T-RFLP (Terminal Restriction Fragments Length Polymorphism) (Saikaly et al, 2005; Marsh et al., 1998), ARDRA (Amplified rDNA Restriction Analysis) (Gich et al., 2000), DGGE (Denaturing Gradient Gel Electrophoresis), TGGE (Temperature Gradient Gel Electrophoresis), (Liu et al., 2000; Yan et al., 2008; Watanabe et al., 1999); as well as 16-23S rDNA fragment amplification - RISA (Ribosomal Intergenic Spacer Analysis) (Fisher and Triplett, 1999; Garcia-Martinez et al., 1999), or amplifying regions between neighboring repetitive elements e.g. ERICPCR (Enterobacterial Repetitive Intergenic Consensus PCR), REP-PCR (Repetitive Extragenic Palindromic PCR) (Versalovic et al., 1991).

In this article we have focused on fingerprint patterns based on REP-PCR. Repetitive extragenic palindromic elements (REP, palindromic units PU) are short sequences best described in Escherichia coli (Dimri et al., 1992; Gilson et al., 1984). REPs consist of two conservative consensus sequences separated by 5 variable nucleotides. After transcription REP makes stable stem-loop structures. 3' end doesn't form a stem-loop structure and determines the orientation of REP (Dimri et al., 1992; Versalovic et al., 1991).

The E. coli chromosome contains about 500-1000 copies of REP. REP may occur single but they are mostly organized in clusters called REP elements (max 10. elements). REP elements are located at the beginning, end or between the genes in operons. (Lupski and Weinstock, 1992; Versalovic et al., 1991). Its distribution among genomic DNA E. coli was described by Dimri in 1992 .

One of the well known functions of REP is that they serve as binding sites for gyrase (Yang and Ames, 1988). REP are also recognized by insertion sequences (Choi et al., 2003), DNA polymerase and DNA bending integration host factor (Tobes and Ramos, 2005). Because of 3' mRNA flanking by REP it is said that REP stabilizes mRNA and protected it from degradation (Gilson et al., 1984).

Many articles suggest that REPs are characteristic elements not only for Eubacteria but are widely distributed throughout the bacterial kingdom (Tobes and Ramos, 2005). Because of conservative regions in REP elements - using consensus primers allows us to amplify regions between neighboring repetitive elements and generates fingerprints characteristic for populations, species or strains. In spite of the fact that REPPCR are mostly used to identify species and strains (e.g. Staphylococcus aureus, S. pneumoniae (Woods et al., 1993), Acinetobacter (Snelling et al., 1996), the aim of this study was to find differences between populations in non-bulking and bulking activated sludge using patterns of REP-PCR products. We did try to verify whether REP-PCR fingerprinting is applicable to activated sludge sample differentiation and might be used as an effective tool for flock organisms typing based on DNA analysis.

\section{Experimental}

\section{Materials and Methods}

Sewage samples. In the period from August 2007 to February 2009, a 1.5-year investigation of activated sludge condition at the "Wschód" wastewater treatment plant (WWTP) in Łaziska Górne, Poland was carried out. WWTP "Wschód" is a mechanical-biological plant, which receives and treats about $2300 \mathrm{~m}^{3} /$ day of domestic wastes (8000 population equivalents - PE, 5 day biochemical oxygen demand of $60 \mathrm{~g}$ of oxygen per day). To mechanical treatment mechanical screens, 2 sand traps and 2 primary sedimentation tanks are used. Biological treatment units consist of 2 bio- 
reactors. Organic substances are eliminated during nitrification, denitrification and dephosphatation processes which occur in anaerobic, anoxic and aeration chambers of bioreactors. In a short-term remedial strategy, according to the Polish Standards for water and wastewater ferric sulphate (PIX, Kemipol-Police) is added to support the elimination of phosphorus. Thereafter mixed liquor flows to secondary sedimentation tanks from which after sedimentation, part of the activated sludge is recirculated to the bioreactor.

Mixed liquor samples were collected 1-2 times a month from aeration basin; altogether 30 activated sludge samples were collected.

During sampling time the bulking problem was observed from August 2007 till February 2008. In detail, samples collected in the period from 06.08.2007 to 27.02.2008 were collected from a bulking sludge and samples collected in the period from 09.04.2008 to 17.02 .2009 were collected from a non-bulking activated sludge. The technical conditions of the treatment process and parameters of wastewater during sample collection were comparable for both groups of activated sludge. The bulking phenomenon was evaluated generally on the basis of microscopic observations. The amount of filamentous bacteria present in activated sludge flocks was value based on a scale from one to five, following Michałkiewicz et al., 2003. The number of filaments observed in non-bulking activated sludge flocks averaged 1-5 per flock. Flocks of bulking sludge were closely packed with over 20 filaments. Moreover, conventional monitoring of activated sludge and sewage, according to the Polish Standards for water and wastewater, was performed at WWTP "Wschód". Physico-chemical analysis of activated sludge samples-value of sludge volume index (SVI), suspension mass $(\mathrm{g})$ and sedimentation $(\mathrm{ml} / \mathrm{l})$ were included into sludge samples classification. All samples were analyzed within 30 minutes of collection time, and for molecular analysis the samples were immediately transported to the Department of Biotechnology and Genetic Engineering, Medical University of Silesia, Poland.

DNA extraction and purification. For DNA extraction $30 \mathrm{ml}$ of activated sludge samples was centrifuged at $800 \times \mathrm{g}$ for $10 \mathrm{~min}$ (Eppendorf Centrifuge 5415 D, Eppendorf neoLab). After discarding the supernatant $0.25 \mathrm{~g}$ of the activated sludge was resuspended in $625 \mu \mathrm{l}$ extraction buffer containing: $100 \mathrm{mM}$ Tris-HCl, $\mathrm{pH} 8.0 ; 100 \mathrm{mM}$ sodium EDTA, $\mathrm{pH} 8.0 ; 100 \mathrm{mM}$ sodium phosphate, $\mathrm{pH} 8.0(93.2 \mathrm{ml}$ $1 \mathrm{M} \mathrm{Na}_{2} \mathrm{HPO}_{4}, 6.8 \mathrm{ml} 1 \mathrm{M} \mathrm{NaH}_{2} \mathrm{PO}_{4}$ ); $1.5 \mathrm{M} \mathrm{NaCl}$; $1 \%$ CTMP (cetyltrimethylammonium bromide). $50 \mu 1$ of enzyme mixture I (lysozyme $900000 \mathrm{U} / \mathrm{ml}$ $-10 \mathrm{mg} / \mathrm{ml}$; lipase type VII $20000 \mathrm{U} / \mathrm{ml}-30 \mathrm{mg} / \mathrm{ml}$; pectinase $1 \%-135 \mathrm{mg} / \mathrm{ml}$ ) was added and samples were incubated for $30 \mathrm{~min}$ at $37^{\circ} \mathrm{C}$. After incubation a protease mix was added: $25 \mu \mathrm{l}$ pronase $\mathrm{P}$ (protease type XIV) $20 \mathrm{mg} / \mathrm{ml}$, and $10 \mu \mathrm{l}$ of proteinase $\mathrm{K}$ (1000 U/ml, Fermentas) for additional $30 \mathrm{~min}$ incubation at $37^{\circ} \mathrm{C}$. Then $150 \mu \mathrm{l}$ of $10 \%$ SDS was added and samples were transported for incubation at $65^{\circ} \mathrm{C}$ for an additional 2 hrs (Purkhold et al., 2000). The next step was addition of $600 \mu \mathrm{l}$ of a mixture of phenol-chloroform-isoamyl alcohol $(25: 24: 1)$ and incubation of samples for $20 \mathrm{~min}$ at $65^{\circ} \mathrm{C}$. Following centrifugation for $10 \mathrm{~min}$ at $10000 \times \mathrm{g}$ at room temperature aqueous phase was transferred to a new Eppendorf tube. To the aqueous phase 1 volume of chloroform-isoamyl alcohol (24:1) mixture was added, and the samples were centrifuged for $10 \mathrm{~min}$ at $10000 \times \mathrm{g}$. The transferred supernatant treated with 0.6 volumes of isopropanol was incubated at RT for 1 hour and then centrifuged for $20 \mathrm{~min}$ at $10000 \times \mathrm{g}$. After centrifugation, the supernatant was discarded and the pellet was washed with $0.5 \mathrm{ml}$ of $70 \%$ ethanol, dried and resuspended in $50 \mu$ of buffer $(10 \mathrm{mM}$ Tris- $\mathrm{HCl}$ o $\mathrm{pH} 8.5$ ).

Efficiency of DNA isolation was determined by using spectrophotometer BioPhotometr, Eppendorf. Optical density was measured at 260 and $280 \mathrm{~nm}$. To determine the purity of DNA the $\mathrm{A}_{260} / \mathrm{A}_{280}$ ratio was calculated.

Repetitive Extragenic Palindromic PCR - REPPCR. REP-PCR conditions used in the current study were adapted from Versalovic et al. (1991); however, the amount of DNA added to the PCR mixture needed to be optimized. For REP-PCR standardization 10, 50 and $100 \mathrm{ng}$ of isolated total DNA was used. PCR reactions were done in $15 \mu \mathrm{l}$ of total volume consisted of: 1x Master Amp ${ }^{\mathrm{TM}} \mathrm{Tfl}$ PCR buffer, $3 \mathrm{mM} \mathrm{MgCl}{ }_{2}$, $3 x$ Master AMP ${ }^{T M}$ PCR enhancer with betaine, $0.2 \mathrm{mM}$ of each dNTP, $0.4 \mu \mathrm{M}$ of primers Rep1 and Rep2 (Table I), $0.3 \mathrm{U}$ of Master Amp ${ }^{\mathrm{TM}} \mathrm{Tfl}$ DNA Polymerase.

Table I

Nucleotide sequence of REP-PCR primers used for activated sludge samples DNA analysis. The I denotes inosine.

The arrow denotes the direction of $T f l$ polymerase extension.

\begin{tabular}{|l|l|c|}
\hline $\begin{array}{c}\text { Primer } \\
\text { symbol }\end{array}$ & \multicolumn{1}{|c|}{ Sequence $\left(5^{\prime} \rightarrow 3^{\prime}\right)$} & Reference \\
\hline Rep F & IIICGICGICATCIGG & Versalovic et al., 1991 \\
\hline Rep R & CGICTTATCIGGCCTAC & Versalovic et al., 1991 \\
\hline
\end{tabular}

Thermal cycling conditions were as follows: initial denaturation $95^{\circ} \mathrm{C}, 7 \mathrm{~min} ; 35$ cycles denaturation $90^{\circ} \mathrm{C}, 30 \mathrm{~s}$; annealing $40^{\circ} \mathrm{C}, 1 \mathrm{~min}$; elongation $65^{\circ} \mathrm{C}$, $8 \mathrm{~min}$ and single final extension step: $72^{\circ} \mathrm{C}, 10 \mathrm{~min}$. The reactions were conducted on thermal Mactercycler (Eppendorf).

Computer-assisted REP-PCR DNA fingerprint analysis. After REP-PCR samples containing 
approximately equal amounts of PCR amplicons ( $15 \mu 1$ of post-PCR mixture based on $100 \mathrm{ng}$ of template DNA amplification) were loaded onto electrophoretic gels. All REP-PCR products were separated on $1.5 \%$ agarose electrophoresis gel and visualized using ethidium bromide staining $(0.5 \mathrm{mg} / \mathrm{ml})$. After separation, all gels were digitalized with gel documentation system LabWorks ${ }^{\mathrm{TM}}$ 4.0. Ultra-Violet Products Ltd. (Cambridge, UK) program, size evaluation and integrated optical density (IOD) of each REP-PCR products were done. Size of REP-PCR products were evaluated based on simultaneous Lambda - pUC Mix Marker 4 and 8 (Fermentas) gel separation. Because of some gel distortion (see electrophoresis result e.g. 17.12.2007 and 17.01.2008) the position of the bands on each lane and gel were normalized using DNA molecular weight standards.

Statistical analysis. Statistical analysis of IOD results for particular bands of non-bulking and bulking sludge was conducted by using STATISTICA v. 6,0 (StatSoft Polska) program. In order to compare both group of activated sludge we used Student's t-distribution (normal distribution) and Mann-Whitney U test. Statistical significance $p$ was settled $\leq 0.05$. The DNA fingerprints were statistically analyzed using SYSTAT for Windows version 5 (SAS Institute Inc., Evanston, I11). Cluster analysis of average linkages of the RepPCR fingerprinting patterns was performed by using the Ward's method. The dissimilarity measure used in the Ward's algorithm was the Euclidean distance.

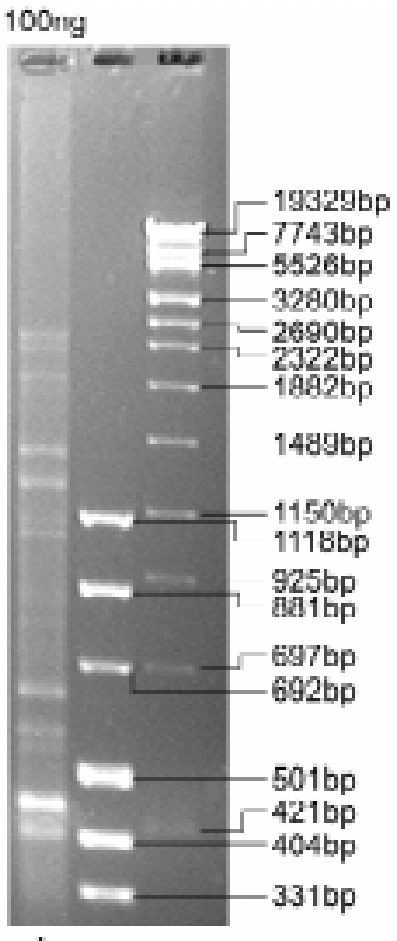

A

\section{Results and Discussion}

REP-PCR. The employed DNA extraction and purification method was very efficient. The average DNA concentration for all 30 activated sludge samples was $1175 \pm 320 \mathrm{ng} / \mu \mathrm{l}$ and the average $\mathrm{A}_{260} / \mathrm{A}_{280}$ ratio was $1.7 \pm 0.08$, reflecting good quality of isolated DNA. To get reproducible REP-PCR results different concentrations of isolated DNA template for amplification reaction were used. The results of PCR standardization are shown in Fig. 1. The best REP-PCR efficiency was found for $100 \mathrm{ng}$ of template DNA, and this concentration was used for the analysis of all samples.

Complex patterns of fingerprints have been obtained for all the examined samples. Generally, the electrophoretic analysis of REP-PCR products revealed in particular electrophoretic paths about 22 bands with determined different size. The product size ranged from $2901 \mathrm{bp}$ to about $400 \mathrm{bp}$. DNA fingerprints generated by REP-PCR with isolated DNA template are shown in Fig. 2 and Fig. 3. Products ranging from 1535-1121 bp and 886-400 bp were commonly observed, and the greatest diversity of DNA fingerprints was observed within the range $1535-400 \mathrm{bp}$. Statistical analysis was done only for representative bands which were present in the majority of samples.

The genomic DNA based REP-PCR patterns were different for bulking and non-bulking activated sludge. Differences between the number and intensity of bands detected on the electrophoregrams representing these

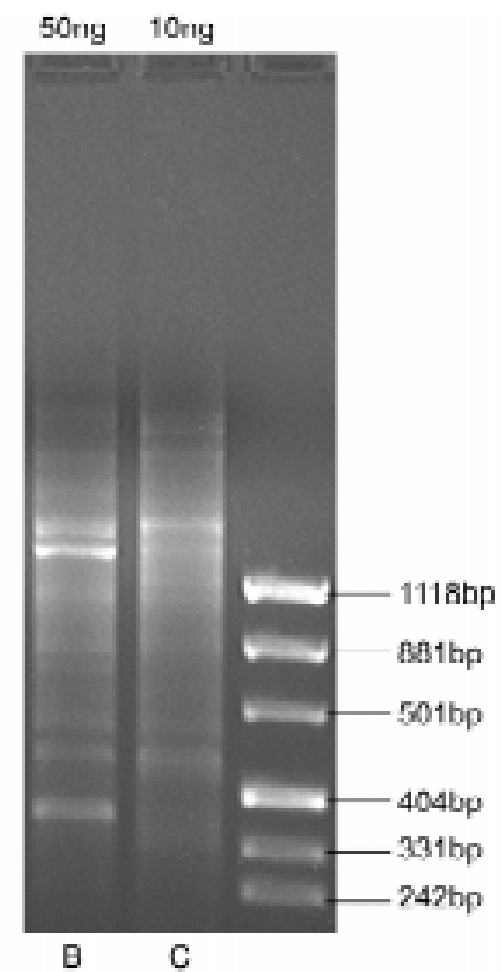

Fig. 1. Representative picture of REP-PCR optimization. DNA Ladder, size markers (in base pairs) are shown on the right. The pattern of PCR products generated by using REP primers and different DNA concentration: $1 \mathrm{~A}-100 \mathrm{ng}, 1 \mathrm{~B}-50 \mathrm{ng}$ and $1 \mathrm{C}-10 \mathrm{ng}$ of DNA template. 


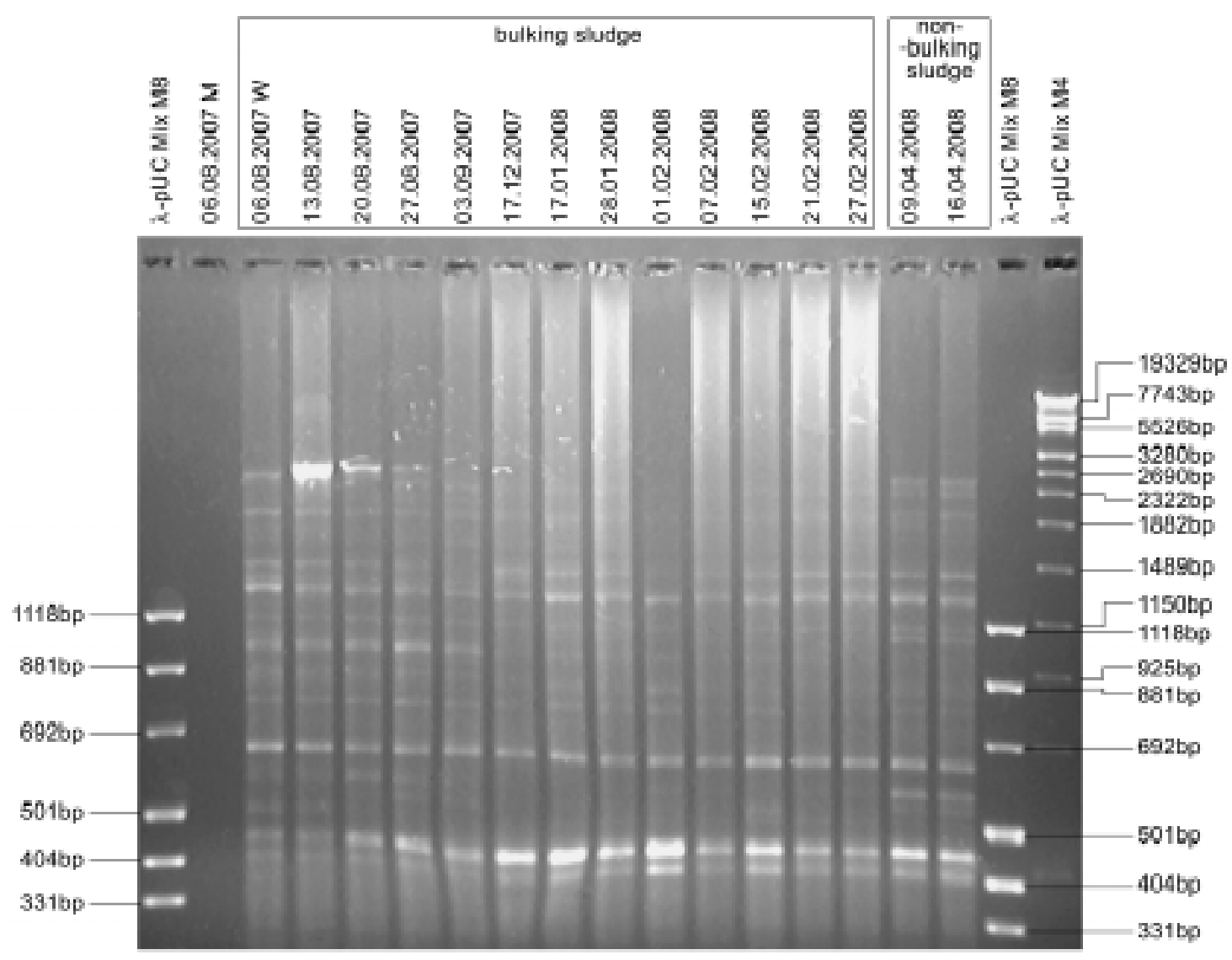

Fig. 2. REP-PCR patterns of activated sludge samples collected from 06.08.2007 to 16.04.2008.

DNA molecular weight standards (in base pairs) (lanes labeled $\lambda$ pUC MIX) are indicated on the left and right.

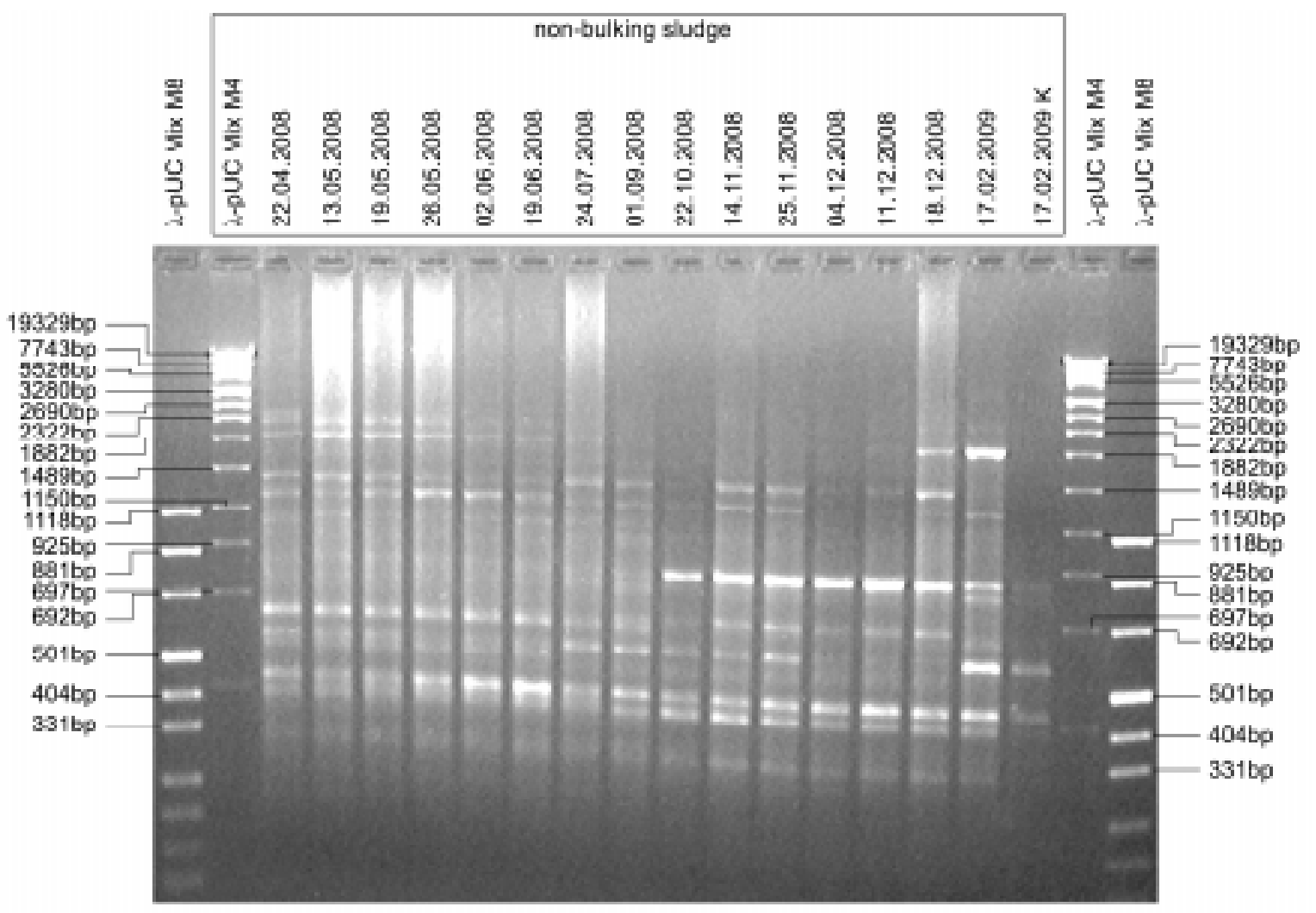

Fig. 3. REP-PCR patterns of activated sludge samples collected from 22.04.2008 to 17.02.2009.

DNA molecular weight standards (in base pairs) (lanes labeled $\lambda$ pUC MIX) are indicated on the left and right. 


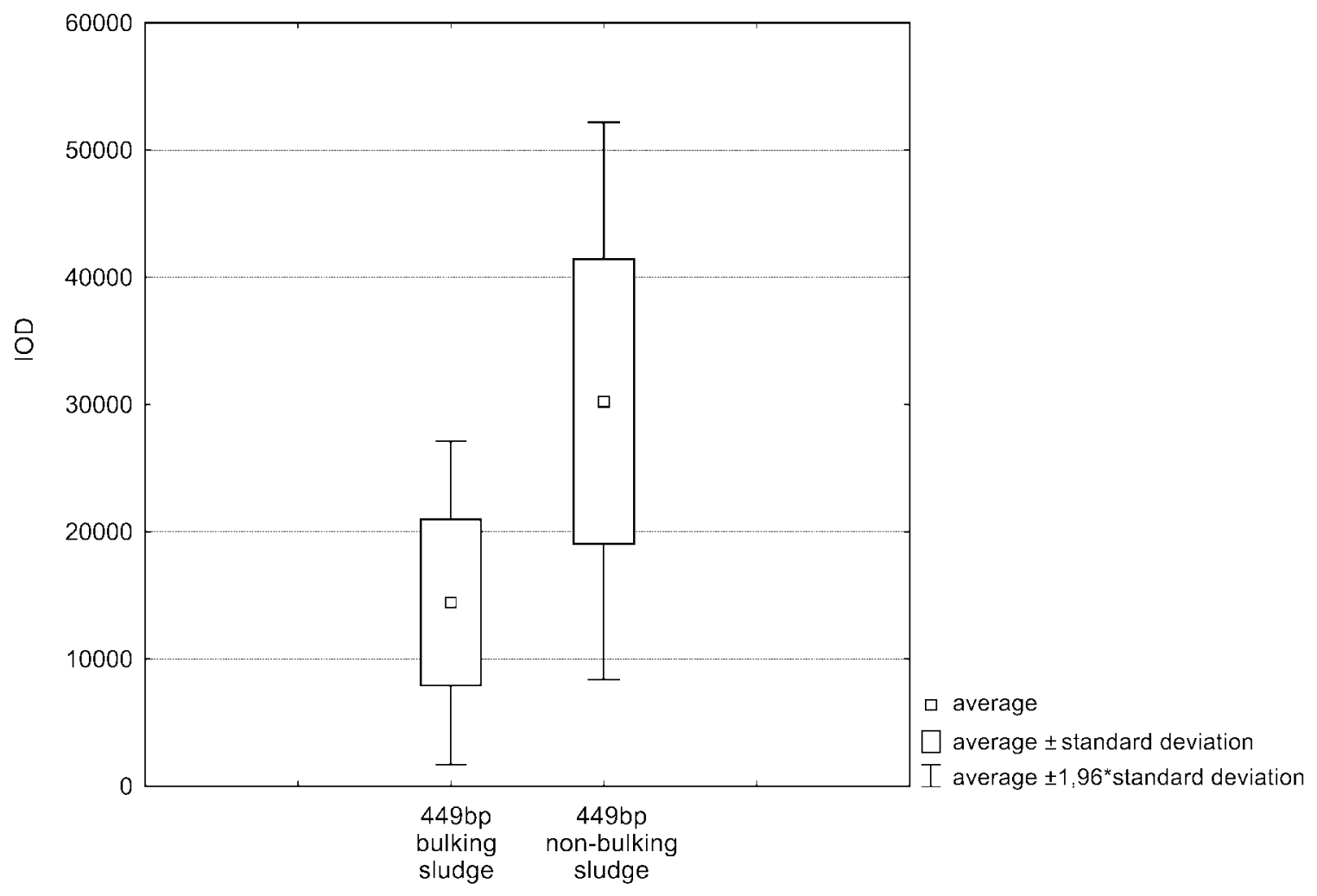

Fig. 4. Results of student's t distribution test for IOD 449 bp bands in non-bulking and bulking activated sludge groups.

two groups of samples were obviously distinct. IOD of the same size bands of non-bulking and bulking sludge fingerprints was compared. Statistically significant differences in IOD values between both groups of sludge samples were received for three characteristic bands with average size: 449, 501 and $685 \mathrm{bp}$. Statistical analysis for IOD of a $449 \mathrm{bp}$ band is shown in Table II.
In the group of non-bulking activated sludge samples IOD values for 449 bp bands were higher than in group of bulking sludge samples, (Student's t-distribution test: $p=0.0001$; Fig. 4).

For 501 and $685 \mathrm{bp}$ bands the Mann-Whitney $\mathrm{U}$ test was conducted. Statistical analysis for IOD of 501 and $685 \mathrm{bp}$ bands of both type of sludge samples is shown in Table III.

Table II

Statistical analysis IOD values of 449 bp band for non-bulking and bulking activated sludge REP-PCR patterns.

\begin{tabular}{|l|c|c|c|c|c|}
\hline $\begin{array}{c}\text { Type of activated } \\
\text { sludge sample }\end{array}$ & Band size & Average IOD & $\min$. IOD & $\max$. IOD & $\begin{array}{c}\text { Standard deviation } \\
\text { (SD) }\end{array}$ \\
\hline non-bulking & $449 \mathrm{bp}$ & 30241.73 & 9749.400 & 49923.0 & 11165.96 \\
\hline bulking & $449 \mathrm{bp}$ & 14446.02 & 6475.700 & 29708.0 & 6490.35 \\
\hline
\end{tabular}

Table III

Statistical analysis IOD values of 501 and 685 bp bands for non-bulking and bulking activated sludge REP-PCR patterns.

\begin{tabular}{|l|c|c|c|c|}
\hline $\begin{array}{c}\text { Type of activated } \\
\text { sludge sample }\end{array}$ & The band size & IOD median & $\begin{array}{c}\text { First quartile } \\
\left(25^{\text {th }} \text { percentile }\right)\end{array}$ & $\begin{array}{c}\text { Third quartile } \\
\left(75^{\text {th }} \text { percentile }\right)\end{array}$ \\
\hline non-bulking & $501 \mathrm{bp}$ & 3917.6 & 2171.5 & 21751.0 \\
\hline bulking & $501 \mathrm{bp}$ & 24396.0 & 18773.0 & 35225.0 \\
\hline non-bulking & $685 \mathrm{bp}$ & 1767.6 & 1538.2 & 2320.9 \\
\hline bulking & $685 \mathrm{bp}$ & 10660.0 & 9023.7 & 11394.0 \\
\hline
\end{tabular}




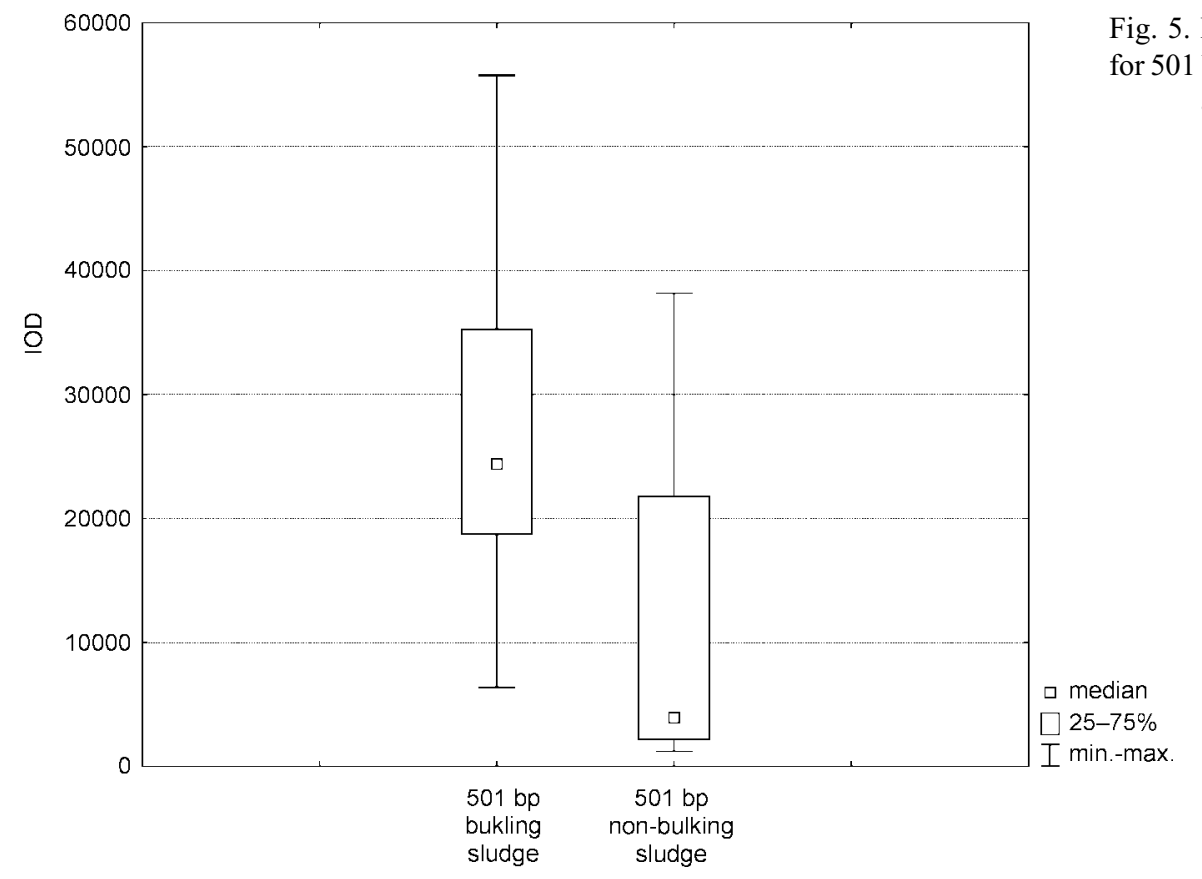

Fig. 5. Results of Mann-Whitney U test result for $501 \mathrm{bp}$ band IOD in non-bulking and bulking activated sludge sample groups.

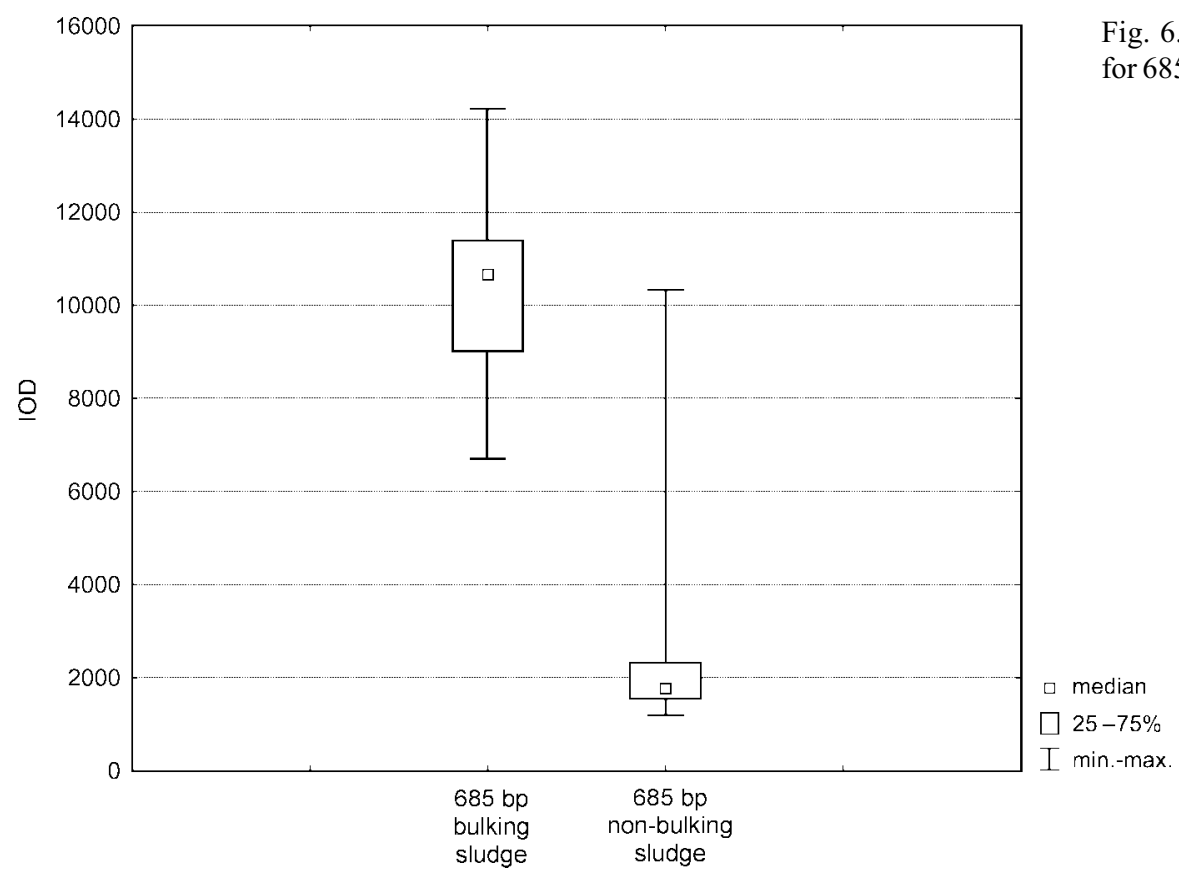

Fig. 6. Results of Mann-Whitney U test result for $685 \mathrm{bp}$ band IOD in non-bulking and bulking activated sludge sample groups.

Mann-Whitney U test results for $501 \mathrm{bp}$ and $685 \mathrm{bp}$ IOD bands for group of non-bulking and bulking sludge samples are shown in Fig. 5 and 6 respectively.

In the case of 501 and $685 \mathrm{bp}$ bands, IOD values evaluated for non-bulking activated sludge samples were lower than for bulking sludge values respectively. The observed difference was statistically significant for both fingerprint patterns $(p=0.0075$ in the case of $501 \mathrm{bp}$ bands IOD and $\mathrm{p}=0.0001$ for 685 bp bands IOD).

Using Ward's method, a dendrogram based on REP-PCR fingerprinting pattern was created (Fig. 7). Cluster analysis was done using an average size of common fingerprinting pattern bands. The dendrogram obtained from REP-PCR fingerprints has grouped the analyzed sludge samples into two main similarity groups, designated A and B branches on the dendrogram tree. Part A of the created dendrogram was composed of 19 samples, but, what is interesting, all bulking sludge samples were grouped into this part of dendrogram tree. Samples within cluster B represented a set of 11 non-bulking activated sludge probes. Cluster A was more complex, but all sludge samples collected during winter bulking time were placed within closely related branches of the dendrogram tree. Unexpectedly, samples from April and May 2008, described as non-bulking activated sludge samples, constituted separate groups within A cluster, 


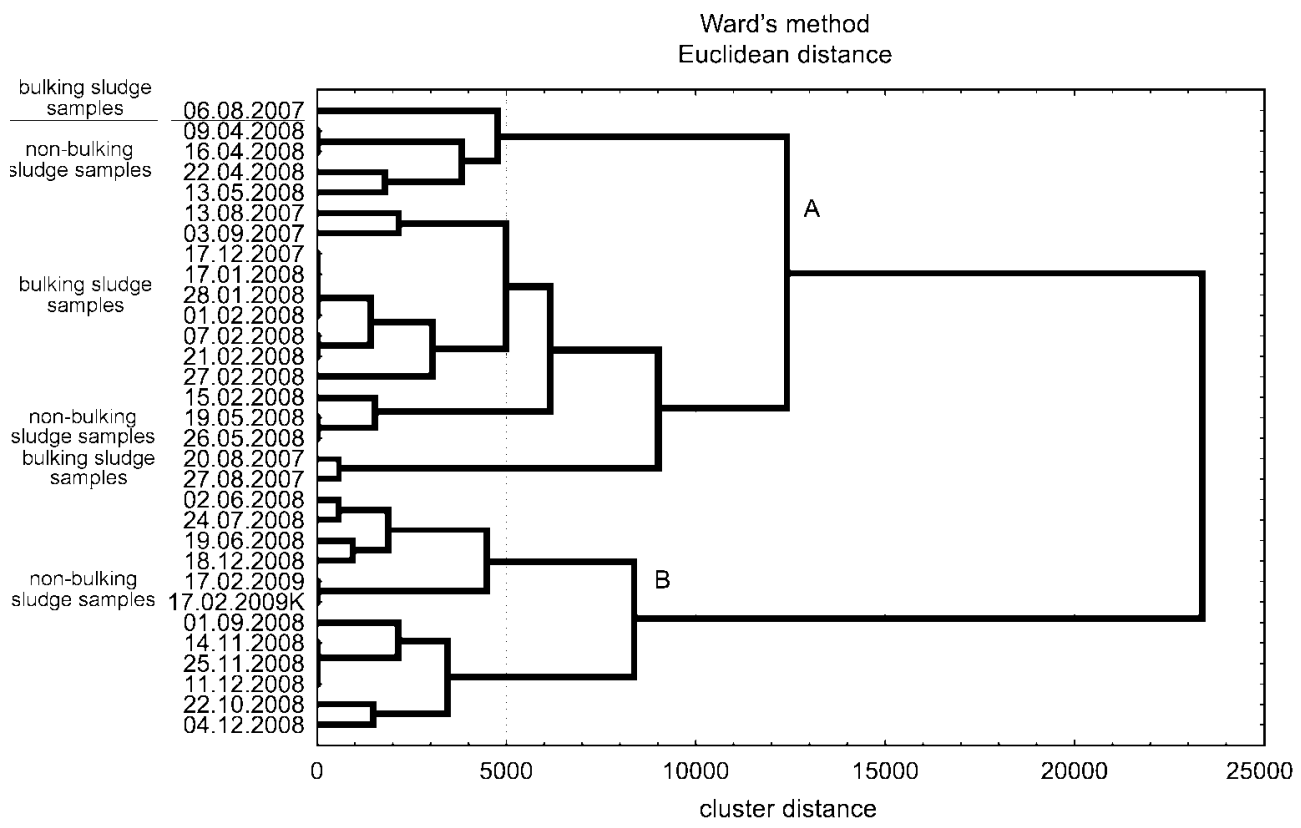

Fig. 7. Hierarchical clustering analysis (Ward's method/Euclidean distance) of non-bulking and bulking sludge samples based on REP-PCR fingerprinting patterns.

where all bulking sludge samples were grouped. These samples characterized at WWTP "Wschód" Łaziska by using screening microscopic analysis (data not shown in this study) revealed common or numerous filaments in a microscopic field and relatively high sedimentation volumetric index, however still lower than in the case of analyzed bulking sludge. It could be that these samples represented sludge parts with abnormal bacterial community mirroring the beginning or ending of the reorganization stage of flocks, and probably starting or ending bulking problem of analyzed activated sludge. We can hypothesize, that REP-PCR fingerprinting patterns reflect early symptoms of bulking and this DNA-based sludge characterization allows the finding lof abnormalities before visual bulking symptoms are visible.

The fact that REP elements are widespread in a bacterial community (Versalovic et al., 1991) motivated us to try to use the REP-PCR method to characterize bacterial population in activated sludge samples collected from WWTP "Wschód" Łaziska Górne, Poland. Excessive growth of filamentous bacteria results in bulking sludge is a undesirable phenomenon which occur in most WWTP's using activated sludge to wastewater treatment. Early detection of this problem allows for a fast reaction to stop bulking. As a criterion of bulking process the sludge volumetric index (SVI) is very often defined. SVI higher than $150 \mathrm{mg} / \mathrm{l}$ suggests a problem with bulking (Eikelboom and Buijsen, 1999). This physical parameter, in the technical aspect, is a very simple method of bulking process evaluation; however it doesn't give information about microbial species responsible for bulking or current correlation in microorganisms' biocenosis of activated sludge. Microscopic observation is shown to be a good method to determine dominant species in bulking activated sludge flocks. A basic disadvantage of this method is the need for very good personnel experience in microscopic examination. Moreover, the morphology of bacteria can vary depending on environmental conditions which cause difficulty of bacteria classification. (Kanagawa et al., 2000). Good solutions for reliable bulking sludge studies seem to be molecular methods, based on DNA or RNA analysis. While widespread distribution of repetitive extragenic elements in the genomes of various microorganisms is seen, REP-PCR method should enable rapid identification and classification of bacterial community. Moreover knowledge of REP-PCR patterns typical for bacteria most responsible for bulking (e.g. Microthrix parvicella, Nostocoida limicola, 021N) (Eikelboom and Geurkink, 2002) should easily help to define species causing bulking.

According to our studies REP-PCR was a good method to show differences in bacterial population in non-bulking and bulking sludge. Ward's cluster analysis enabled to show phylogenetic relation between estimated DNA fingerprints. Finally, the received results show, that applying the clustering method to statistical analysis of REP-PCR fingerprints has made it possible to discriminate and group sludge samples revealing the condition of the sludge and recognizing bulking process symptoms.

Conclusions. The presented study found that employment of PCR and REP primers described by Versalovic 
et al. (1991) can be used for differentiation of sludge samples and preliminary classification into nonbulking or bulking type. Oligonucleotides matching Repetitive Extragenic Palindromic (REP) elements in amplification reaction produced band patterns - DNA fingerprints - sensitive enough to be useful for sludge microbial communities' analysis. It could be concluded that the presented method of the activated sludge analysis, involving the molecular analysis of total genomic DNA, simplifies bulking process evaluation, and constitutes a valuable complement to the physicochemical classification techniques. Moreover, it is economical with regard to time and money, which is important for routine sludge examination. Regarding specifications of activated sludge plants and the type of wastewater being treated, REP-PCR method and statistical analysis of fingerprinting patterns seem to be an effective method with practical approach.

\section{Acknowledgments}

This study was financially supported by a research grant No.: N205 046 32/2534, subsidized by Ministry of Science and Higher Education, Poland; Research coordinator: Ilona A. Bednarek, PhD, dribednarek@sum.edu.pl; Department of Biotechnology and Genetic Engineering Medical University of Silesia, Poland.

We thank Ewa Biedrzycka, WWTP "Wschód" Łaziska Górne for her assistance in carrying out these studies and her excellent technical assistance with the activated sludge sampling.

\section{Literature}

Baker C.J., R.R. Fulthorpe and K.A. Gilbride. 2003. An assessment of variability of pulp mill wastewater treatment system bacterial communities using molecular methods. Water Qual. Res. J. Can. 38: 227-42.

Carr E.L., P. Kampfer, B.K.C. Patel, V. Gutler and R.J. Seviour. 2003. Seven novel species of Acinetobacter isolated from activated sludge. Int. J. Syst. Evol. Microbiol. 53: 953-963.

Choi S., S. Ochta and E. Ohtsubo. 2003. A novel IS element, IS621, of the IS110/IS492 family transposes to a specific site in repetitive extragenic palindromic sequences in Escherichia coli. J. Bacteriol. 185: 4891-4900.

Dimri G.P., K.E. Rudd, M.K. Morgan, H. Bayat and G.F-L. Ames. 1992. Physical Mapping of Repetitive Extragenic Palindromic Sequences in Escherichia coli and Phylogenetic Distribution among Escherichia coli Strains and Other Enteric Bacteria. J. Bacteriol. 174: 4583-4593.

Eikelboom D.H. and H.J.J. Van Buijsen. 1999. Text-book of microscopic studies of activated sludge (in Polish). SeidelPrzywecki, Szczecin.

Eikelboom D.H. and B. Geurkink. 2002. Filamentous microorganisms observed in industrial activated sludge plants. Water Sci. Technol. 46: 535-542.

Fisher M.M. and E.W. Triplett. 1999. Automated approach for ribosomal intergenic spacer analysis of microbial diversity and its application to freshwater bacterial communities. Appl. Environ. Microbiol. 65: 4630-4636.

Garcia-Martinez J., S.G. Acinas, A.I. Anton and F. RodriguezValera. 1999. Use of the 16S-23S ribosomal genes spacer region in studies of prokaryotic diversity. J. Microbiol. Methods. 36: $55-64$.
Gich F.B., E. Amer, J.B. Figueras, C.A. Abella, M.D. Balaguer and M. Poch. 2000. Assessment of microbial community structure changes by amplified ribosomal DNA restriction analysis (ARDRA). Int. Microbiol. 3: 103-106

Gilbride K.A. and R.R. Fulthorpe. 2004. A survey of the composition and diversity of bacterial populations in bleached kraft pulp-mill wastewater secondary treatment systems. Can. J. Microbiol. 50: 633-44.

Gilson E., J-M. Clement, D. Brutlag and M. Hofnung. 1984 A family of dispersed repetitive extragenic palindromic DNA sequences in E. coli. EMBO J. 3: 1417-1421.

Hossain F. 2004. Activated sludge bulking: a review of causes and control strategies. Environ. Eng. 85:1-6.

Kalisz L. and M. Kaźmierczuk. 1998. Organisms of activated sludge. Microscopic studies (in Polish). Instytut Ochrony Środowiska. Dział Wydawnictw IOŚ, Warszawa.

Kanagawa T., Y. Kamagata, S. Aruga, T. Kohno, M. Horn and M. Wagner. 2000. Phylogenetic analysis of and oligonucleotide probe development for Eikelboom type 021N filamentous bacteria isolated from bulking activated sludge. Appl. Environ. Microbiol. 66: 5043-5052.

Lacko N., F. Bux and H.C. Kasan. 1999. Survey of filamentous bacteria in activated sludge plants in KwaZulu-Natal. Water $S A$. 25: 63-68.

Liao J., I. Lou and F.L. de los Reyes III. 2004. Relationship of species-specific filament levels to filamentous bulking in activated sludge. Appl. Environ. Microbiol. 70: 2420-2428.

Liu W-T., K.D. Linning, K. Nakamura, T. Mino, T. Matsuo and L.J. Forney. 2000. Microbial community changes in biological phosphate-removal systems on altering sludge phosphorus content. Microbiology. 146: 1099-1107.

Lupski J.R. and G.M. Weinstock. 1992. Minireview. Short, interspersed repetitive DNA sequences in prokaryotic genomes. J. Bacteriol. 174: 4525-4529.

Marsh T.L., W-T. Liu, L.J. Forney and H. Cheng. 1998 Beginning a molecular analysis of the eukaryal community in activated sludge. Water. Sci. Technol. 37: 455-460

Martins A.M.P., J.J. Heijnen and M.C.M. van Loosdrecht. 2003. Effect of feeding patter and storage on the sludge settleability under aerobic conditions. Water Res. 37: 2555-2570.

Mehandjiyska L. 1995. Microbiological analysis of activated sludge in municipal wastewater treatment plant at "Kremikovtzi" holding. J. Cult. Collect. 1: 18-22.

Michałkiewicz M. and M. Fiszer. 2003. Sanitary biology (in Polish). Wydawnictwo Politechniki Poznańskiej. Poznań.

Otawa K., R. Asano, Y. Oba, T. Sasaki, E. Kawamura, F. Koyama, S. Nakamura and Y. Nakai. 2006. Molecular analysis of ammonia-oxidizing bacteria community In intermittent aeration sequencing batch reactors used for Animals wastewater treatment. Environ. Microbiol. 8: 1985-96.

Purkhold U., A. Pommerening-Roser, S. Juretschko, M.C. Schmid, H-P. Koops and M. Wagner. 2000. Phylogeny of all recognized species of ammonia oxidizers based on comparative $16 \mathrm{~S}$ rRNA and amoA sequence analysis: implications for molecular diversity surveys. Appl. Environ. Microbiol. 66: 5368-5382. Saikaly P.E., P.G. Stroot and D.B. Oerther. 2005. Use of $16 \mathrm{~S}$ rRNA gene terminal restriction fragment analysis to assess the impact of solids retention time on the bacterial diversity of activated sludge. Appl. Environ. Microbiol. 71: 5814-5822.

Snelling A.M., P. Gerner-Smidt, P.M. Hawkey, J. Heritage, P. Parnell, C. Porter, A.R. Bodenham and T. Inglis. 1996. Validation of use whole-cell repetitive extragenic palindromic sequence-based PCR (REP-PCR) for typing strains belonging to the Acinetobacter calcoaceticus-Acinetobacter baumanii - complex and application of the method to the investigation of Hospital Outbreak. J. Clin. Microbiol. 34: 1193-1202. 
Tobes R. and J-L. Ramos. 2005. REP code; defining bacterial identity in extragenic space. Environ. Microbiol. 7: 225-228.

Versalovic J., T. Koeuth and J.R. Lupski. 1991. Distribution of repetitive DNA sequences in eubacteria and application to fingerprinting of bacterial genomes. Nucleic Acids Res. 19: 6823-6831. Wang J-B., L-H. Chai, Y. Zhang and L-M. Chen. 2006. Microbial ecological model of filamentous bulking and mechanisms. World J. Microbiol. Biotechnol. 22: 1313-1320.

Watanabe K., M. Teramoto and S. Harayama. 1999. An outbreak of nonflocculating catabolic populations caused the breakdown of a phenol-digesting activated-sludge process. Appl. Environ. Microbiol. 65: 2813-2819.

Woods C.R., J. Versalovic, T. Koeuth and J.R. Lupski. 1993. Whole-cell repetitive element sequence-based polymerase chain reaction allows rapid assessment of clonal relationships of bacterial isolates. J. Clin. Microbiol. 31: 1927-1931

Yan S., K. Miyanaga, X-H. Xing and Y. Tanji. 2008. Succession of bacterial community and enzymatic activities of activated sludge by heat-treatment for reduction of excess sludge. Biochem. Eng. J. 39: 598-603.

Yang Y. and G. F-L Ames. 1988. DNA gyrase binds to the family of prokaryotic repetitive extragenic palindromic sequences. Proc. Natl. Acad. Sci. U. S. A. 85; 8850-8854

Ziembińska A., A. Raszka, J. Truu, J. Surmacz-Górska and K. Miksch. 2007. Molecular analysis of temporal changes of bacterial community structure in activated sludge using denaturing gradient gel electrophoresis (DGGE) and Fluorescent in situ hybridization ( FISH). Pol. J. Microbiol. 56: 119-127. 